P154 SAFETY OF TIOTROPIUM IN PRE-SCHOOL CHILDREN WITH SYMPTOMATIC PERSISTENT ASTHMA

10.1136/thoraxjnl-2016-209333.469

$\mathrm{H}$ Bisgaard has been a consultant for AstraZeneca, Boehringer Ingelheim and Chiesi;

M Vandewalker has received research grants and personal fees from Boehringer Ingelheim;

L Graham made no relevant disclosures;

P Moroni-Zentgraf is an employee of Boehringer Ingelheim;

$M$ Engel is an employee of Boehringer Ingelheim;

G El Azzi is an employee of Boehringer Ingelheim;

SD Vulcu is an employee of Boehringer Ingelheim;

$\mathrm{H}$ Finnigan is an employee of Boehringer Ingelheim;

EJLE Vrijlandt has received personal fees from Boehringer Ingelheim

\section{P155 SAFETY OF TIOTROPIUM RESPIMAT@ ADD-ON THERAPY IN PATIENTS AGED 6-17 YEARS WITH SYMPTOMATIC ASTHMA}

10.1136/thoraxjnl-2016-209333.470

C Vogelberg has participated in an advisory board for Boehringer Ingelheim;

SJ Szefler has received personal fees from Aerocrine, Boehringer-Ingelheim, Daiichi Sankyo, Genentech, GlaxoSmithKline, Merck, Novartis, and Roche, and research grants from GlaxoSmithKline;

E Hamelmann has received research grants and other fees from Boehringer Ingelheim and non-financial support from Boehringer Ingelheim;

A Boner has nothing to disclose;

P Moroni-Zentgraf is an employee of Boehringer Ingelheim;

$M$ Engel is an employee of Boehringer Ingelheim;

G El Azzi is an employee of Boehringer Ingelheim;

$\mathrm{H}$ Finnigan is an employee of Boehringer Ingelheim;

$M$ Vandewalker has received research grants and personal fees from Boehringer Ingelheim.

\section{P156 EFFICACY, SAFETY AND TOLERABILITY OF ONCE-DAILY TIOTROPIUM RESPIMAT $®$ ADD-ON THERAPY IN CHILDREN WITH MODERATE SYMPTOMATIC ASTHMA}

10.1136/thoraxjnl-2016-209333.471

O Schmidt has received research grants from Boehringer Ingelheim;

E Hamelmann has received research grants and other fees from Boehringer Ingelheim and non-financial support from Boehringer Ingelheim;

C Vogelberg has participated in an advisory board for Boehringer Ingelheim;

I Laki has nothing to disclose;

G El Azzi is an employee of Boehringer Ingelheim;

$M$ Engel is an employee of Boehringer Ingelheim;
P Moroni-Zentgraf is an employee of Boehringer Ingelheim; $\mathrm{H}$ Finnigan is an employee of Boehringer Ingelheim;

$M$ Vandewalker has received research grants and personal fees from Boehringer Ingelheim.

\section{P183 BURDEN OF ILLNESS IN SCHOOL-AGED PATIENTS WITH CYSTIC FIBROSIS (CF) IN THE UNITED STATES}

10.1136/thoraxjnl-2016-209333.472

J Rubin: is an employee of Vertex Pharmaceuticals Incorporated and may own stock or stock options in that company.

M Bonafede: is employed by Truven Health Analytics which received funding from Vertex Pharmaceuticals Incorporated.

S Sikirica: is an employee of Vertex Pharmaceuticals Incorporated and may own stock or stock options in that company.

B Limone: is employed by Truven Health Analytics which received funding from Vertex Pharmaceuticals Incorporated.

$\mathrm{N}$ Adolph: is employed by Truven Health Analytics which received funding from Vertex Pharmaceuticals Incorporated.

M Konstan: received consultant fees and his institution has received financial support from Vertex Pharmaceuticals Incorporated for study participation.

\section{P294 BENEFITS OF TIOTROPIUM/OLODATEROL OVER TIOTROPIUM AT DELAYING CLINICALLY SIGNIFICANT EVENTS IN PATIENTS WITH COPD CLASSIFIED AS GOLD B}

10.1136/thoraxjnl-2016-209333.473

$\mathrm{R}$ Buhl reports financial support to his institution from Boehringer Ingelheim during the conduct of the study and, outside of the submitted work, financial support from Boehringer Ingelheim, AstraZeneca, Chiesi, Novartis, Teva, Roche and GlaxoSmithKline for attendance at advisory boards and speaking activities, and research support to his institution from Boehringer Ingelheim, GlaxoSmithKline, Novartis and Roche.

L McGarvey reports personal fees from Applied Clinical Intelligence during the conduct of the study, and grants from Asthma UK, NI Chest Heart \& Stroke, NC3Rs, British Heart Foundation and Chiesi, and other from Boehringer Ingelheim, GlaxoSmithKline, Chiesi, Almirall and NAPP outside the submitted work.

$S$ Korn has received grants and personal fees from AstraZeneca, Boehringer Ingelheim, GlaxoSmithKline, Novartis and Takeda, grants from Teva and MedImmune, and personal fees from Almirall and Grifols.

GT Ferguson, during the conduct of the study, reports grants, personal fees and non-financial support from Boehringer Ingelheim and, outside the submitted work, grants, personal fees and non-financial support from Boehringer Ingelheim, personal fees from GlaxoSmithKline, grants and personal fees from Novartis, AstraZeneca, Pearl Therapeutics and Sunovion, and grants from Forest.

L Grönke, C Hallmann and F Voß are employees of Boehringer Ingelheim Pharma GmbH \& Co. KG. 
KF Rabe reports financial for support for consultancy work from AstraZeneca, Chiesi, Novartis, MSD and GlaxoSmithKline, and grants from Altana, Novartis, AstraZeneca, MSD and Nycomed.

F Maltais reports financial support from Boehringer Ingelheim during the conduct of the study and, outside of the submitted work, financial support from Boehringer Ingelheim and GlaxoSmithKline for attendance at advisory boards, financial support from Boehringer Ingelheim, GlaxoSmithKline, AstraZeneca and Novartis for speaking activities, and research support from Boehringer Ingelheim, GlaxoSmithKline, AstraZeneca, Nycomed and Novartis.

\section{P295 EFFICACY AND SAFETY OF TIOTROPIUM/OLODATEROL IN PATIENTS WITH COPD BY ATS CATEGORY}

\subsection{6/thoraxjnl-2016-209333.474}

F Maltais reports financial support from Boehringer Ingelheim during the conduct of the study and, outside of the submitted work, financial support from Boehringer Ingelheim and GlaxoSmithKline for attendance at advisory boards, financial support from Boehringer Ingelheim, GlaxoSmithKline, AstraZeneca and Novartis for speaking activities, and research support from Boehringer Ingelheim, GlaxoSmithKline, AstraZeneca, Nycomed and Novartis.

E Pizzichini has nothing to disclose.

L Grönke and F Voß are employees of Boehringer Ingelheim Pharma GmbH \& Co. KG.

E Derom, outside of the submitted work, reports financial support from Boehringer Ingelheim, Actelion, AstraZeneca and Cipla for consultancy work, financial support from Chiesi, AstraZeneca and CSL Behring for advisory board attendance, and research support from Boehringer Ingelheim and GlaxoSmithKline.

\section{P296 EFFECT OF TIOTROPIUM/OLODATEROL THERAPY ON COPD EXACERBATIONS IN THE TONADO® STUDIES}

\subsection{6/thoraxjnl-2016-209333.475}

E Derom, outside of the submitted work, reports financial support from Boehringer Ingelheim, Actelion, AstraZeneca and Cipla for consultancy work, financial support from Chiesi, AstraZeneca and CSL Behring for advisory board attendance, and research support from Boehringer Ingelheim and GlaxoSmithKline.

M Fležar has received personal fees from Boehringer Ingelheim and institutional financial support from Novartis.

L Grönke and F Voß are employees of Boehringer Ingelheim Pharma GmbH \& Co. KG.

$\mathrm{R}$ Buhl reports financial support to his institution from Boehringer Ingelheim during the conduct of the study and, outside of the submitted work, financial support from Boehringer Ingelheim, AstraZeneca, Chiesi, Novartis, Teva, Roche and GlaxoSmithKline for attendance at advisory boards and speaking activities, and research support to his institution from Boehringer Ingelheim, GlaxoSmithKline, Novartis and Roche.
P297

LUNG-FUNCTION PROFILE BEFORE AND AFTER THE FIRST MODERATE TO SEVERE EXACERBATION DURING THE WISDOM STUDY

10.1136/thoraxjnl-2016-209333.476

E Wouters, outside of the submitted work, reports personal fees from AstraZeneca, GlaxoSmithKline, Novartis, Takeda, Pfizer and Boehringer Ingelheim, and grants from AstraZeneca, GlaxoSmithKline and Novartis.

$\mathrm{H}$ Magnussen received funding from Almirall, AstraZeneca, Boehringer Ingelheim, Chiesi, GlaxoSmithKline, Merck, Novartis, Takeda and Roche to conduct clinical studies, and has spoken at meetings and is a member of advisory boards for these and other companies.

R Rodriguez-Roisin reports personal fees from AstraZeneca, Boehringer Ingelheim, Mylan, Pearl Therapeutics, Takeda, Teva and Ferrer, and grants and personal fees from Menarini and Almirall.

K Tetzlaff and S Bell are employees of Boehringer Ingelheim Pharma GmbH \& Co. KG. PMAC reports financial support in the form of a grant from Boehringer Ingelheim to conduct the study and, outside of the submitted work, reports personal fees from GlaxoSmithKline, AstraZeneca, Takeda and Boehringer Ingelheim, and grants from GlaxoSmithKline and Takeda.

\section{P298 TIOTROPIUM/OLODATEROL THERAPY PROVIDES SYMPTOMATIC BENEFITS IRRESPECTIVE OF PRIOR MAINTENANCE TREATMENT: POST HOC ANALYSES OF THE OTEMTO® STUDIES}

10.1136/thoraxjnl-2016-209333.477

R Abrahams reports grants and personal fees from Boehringer Ingelheim during the conduct of the study and, outside of this work, grants and personal fees from GlaxoSmithKline and grants from AstraZeneca and Pearl Therapeutics.

GT Ferguson, during the conduct of the study, reports grants, personal fees and non-financial support from Boehringer Ingelheim and, outside the submitted work, grants, personal fees and non-financial support from Boehringer Ingelheim, personal fees from GlaxoSmithKline, grants and personal fees from Novartis, AstraZeneca, Pearl Therapeutics and Sunovion, and grants from Forest.

L Bjermer reports no conflicts of interest.

L Grönke and F Voß are employees of Boehringer Ingelheim Pharma GmbH \& Co. KG.

D Singh reports other financial activities from Boehringer Ingelheim during the conduct of the study and, outside of the submitted work, grants and personal fees from Almirall, AstraZeneca, Boehringer Ingelheim, Chiesi, GlaxoSmithKline, Glenmark, Johnson \& Johnson, Merck, NAPP, Novartis, Pfizer, Takeda, Teva, Theravance and Verona, and personal fees from Genentech and SkyePharma. 